\title{
Potential of replacing pawpaw fruit and leaves with cabbage peels as a natural feedstuff in the diet of Achatina achatina linne (African giant land snail)
}

\author{
Imran, G. T. ${ }^{1}$, Ayeni, O. D. ${ }^{2}$, Okunade, A. S. ${ }^{1}$ and Oyeleye, B. ${ }^{1}$ \\ ${ }^{1}$ Forestry Research Institute of Nigeria, P.M.B. 5054, Jericho, Ibadan, Oyo State. \\ ${ }^{2}$ Federal College of Forestry, Jericho, P.M.B. 5054, Jericho, Ibadan, Oyo state.
}

Accepted 10 September, 2009

\begin{abstract}
An experiment was carried out to assess the growth performance of African Giant Land Snail Achatina achatina Linnie fed with three natural feedstuff; pawpaw fruit, pawpaw leaves and cabbage leaves. A total of 24 growing snails of approximately one year old were used for the study. These were randomly divided into six groups and then allotted into the three experimental diets, arranged in a completely randomised design (CRD) order. Dry matter intakes of feed being served every other days, weight gain and size increase of snails were assessed fortnightly. The results showed that pawpaw leaf is higher in protein than cabbage leaf and pawpaw fruit. However, cabbage leaf contains some essential mineral elements, which are useful in body building than the other two feedstuffs. It also showed that snails fed with cabbage leaves had the highest dry matter intake and weight gain of 14.2 and $18.6 \mathrm{~g}$, respectively. Highest shell length and circumference increase of 0.3 and $0.6 \mathrm{~cm}$ were obtained in pawpaw fruit and pawpaw leaf respectively. Although there was no significance difference $(p>0.05)$ in the weight gain of snails fed with pawpaw fruit and cabbage leaves, cabbage leaf seems to be richer in protein and other essential mineral elements than pawpaw fruit. It was therefore concluded that cabbage leaf could serve as a good substitute for pawpaw fruit and leaves, which hitherto were known as the preferred natural feedstuff of snails.
\end{abstract}

Key words: African giant land snail, natural feedstuff, protein, mineral elements.

\section{INTRODUCTION}

Snails are invertebrate, shell bearing animal belonging to the class of Gastropoda Habitually, they preferred very cool environment (F.A.O., 1986). In southern Nigeria, where consumption of snails is very popular, three species of edible land snails-Archachatina marginata, Achatina achatina and Limcolaria spp. are very common. These breeds vary in their adaptability to environment, size at day old, size at maturity, egg size and growth rate (Amusan and Omidiji, 1999). Snail meat is high in protein, low in fats and a source of iron (Osawuyi, 1989). It constitutes an important component of the food of numerous rural dwellers, especially in the rainforest belt as well as other areas of the country where snail eating is not a taboo (Akinnusi, 1989). Snails are predominantly vegetarians

\footnotetext{
*Corresponding author. E-mail: murainagbola@yahoo.com.
}

and can utilise a number of feeds for growth (FAO, 1986; Phillips, 1992; Odunaiya, 1997). In the captivity, leaf and fruit of plants form a major constituent of snail ration and various species of natural feedstuffs have been utilised by various workers. Eruvbetine et al. (1997) and Ademolu et al. (2004) have utilised pawpaw leaf, pawpaw fruit, water leaf and banana fruit while Hamzat et al. (2002) has used kola-nut testa to feed snails. The success of any captive snail rearing programme however depend on the availability and abundant of natural feedstuff. Most of the plants being eaten by snails are seasonal and also have multiple uses. Pawpaw, mango, plantain and banana fruits are of economic importance to man. Efforts should therefore be geared towards sourcing for alternative natural feedstuff for feeding snail apart from the conventional ones that also serve as food for human-being.

At the Forestry Research Institute of Nigeria, Ibadan, 
Table 1. Proximate analysis of the natural feedstuffs.

\begin{tabular}{|l|c|c|c|}
\hline Proximate composition (\%) & Pawpaw fruit & Pawpaw leaves & Cabbage leaves \\
\hline Dry matter content & 89.40 & 21.3 & 94.8 \\
Crude protein content & 0.61 & 32.6 & 20.0 \\
Crude fibre content & 1.8 & 10.5 & 2.0 \\
Ash content & 4.6 & 11.0 & 4.0 \\
Sodium & $3.0 \mathrm{mg}$ & $187.26 \mathrm{mg}$ & $18.0 \mathrm{mg}$ \\
Phosphorus & $5.0 \mathrm{mg}$ & $237.26 \mathrm{mg}$ & $23.0 \mathrm{mg}$ \\
Magnesium & $10.0 \mathrm{mg}$ & $230.72 \mathrm{mg}$ & $15.0 \mathrm{mg}$ \\
Calcium & $24.0 \mathrm{mg}$ & $0.95 \mathrm{mg}$ & $47.0 \mathrm{mg}$ \\
Iron & $0.10 \mathrm{mg}$ & $23.94 \mathrm{mg}$ & $0.59 \mathrm{mg}$ \\
Potassium & $257 \mathrm{mg}$ & $15.39 \mathrm{mg}$ & $246 \mathrm{mg}$ \\
\hline
\end{tabular}

efforts are being made to screen some of the natural feedstuff of plant origin with a view to identifying suitable alternative ones that will not compete with man for food.

This study therefore aimed at evaluating the growth performance of Achatina achatina on cabbage leaves, pawpaw leaves and fruit.

\section{MATERIALS AND METHODS}

\section{Study area}

The study was carried out in the Snailery Unit of the Forestry Research Institute of Nigeria (FRIN), Ibadan between June and July, 2008. FRIN is located on latitude $7.23^{\circ} \mathrm{N}$ and latitude $3.51^{\circ} \mathrm{S}$. The mean minimum and maximum annual temperature and rainfall in 2008 were 28.08 and $32.83^{\circ} \mathrm{C}$ and $1,435.8 \mathrm{~mm}$, respectively.

\section{Rearing unit/system used}

Six (6) plastic baskets each of $37 \times 24 \times 24 \mathrm{~cm}$ were used for the experiment. These were filled with loamy soils collected from FRIN herboratum to a depth of about $3 \mathrm{~cm}$.

\section{Experimental design}

A total of twenty-four (24) growing snails Achatina achatina of weights ranging between $112.5-170 \mathrm{~g}$, procured from Alesinloye market, Ibadan were randomly divided into six portions. Each portion which serve as a replicate, consist of four snails. Two portions made-up of a treatment and these were then allotted to the three experimental diets and arranged in a completely randomised design (CRD) order. The experimental diets were pawpaw leaves, pawpaw fruit and cabbage leaves. Pawpaw leaves and fruit were got from FRIN Herboratum while cabbage leaves were got from the foreign fruit and vegetable market, along Jemibewon road, located at Sabo, Ibadan.

\section{Average dry matter intakes}

This was determined with the aid of a weighing scale calibrated in grammes. Weight of left-over food was removed from the weight of food served every two days.

\section{Average weight gain of snails}

This was done every fortnight by subtracting the initial average weight of snails from the final weight. Weight of individual snails was determined using a weighing scale calibrated in grammes.

\section{Average length and circumference of snail's shell}

The shell length and circumference were determined by subtracting the initial values from the final values taken every fortnight. The shell length was determined by measuring with thread and graduated ruler the distance between the apex and basal margin of the peristome. The shell circumference was also determined by measuring the distance round the shell of the snail at the middle of the shell.

\section{Statistical analysis used}

The mean values of data obtained were calculated. Analysis of variance (ANOVA) was also used to determine the level of probability among the variables (Steel and Torie, 1980).

\section{RESULTS AND DISCUSSION}

The results of the proximate analysis of the three natural feedstuffs used were presented in Table 1. Though all of them are plant-based, but the protein and mineral contents varies. Pawpaw leaf was richest in protein (32.6\%), followed by cabbage leaves $(20.0 \%)$, while pawpaw fruit had the least amount of protein $(0.61 \%)$. Low protein content in pawpaw fruit indicated that it is not a good source of protein but rather can be regarded as carbohydrate and starch-rich diet (Bello et al., 2008). Cabbage and pawpaw leaves also contained important mineral elements such as sodium, calcium, magnesium, phosphorus and iron in higher concentrations than pawpaw fruit (Table 1).

The average dry matter intake, weight gain, shell length and circumference increase of snails fed with the three natural feedstuffs are shown in Table 2. The average dry matter intake of pawpaw fruit was significantly different 
Table 2. Overall performance characteristics of $A$. achatina snails fed with pawpaw fruit, leaves and cabbage leaves over a period of six weeks.

\begin{tabular}{|l|c|c|c|}
\hline \multicolumn{1}{|c|}{ Performance characteristics } & Pawpaw fruit & Pawpaw leaves & Cabbage leaves \\
\hline Av. Qty. of Food Served (g) & 125.0 & 125.0 & 125.0 \\
Av. Dry Matter Intake ( g/snail ) & $12.3^{\mathrm{a}}$ & $8.9^{\mathrm{b}}$ & $14.2^{\mathrm{a}}$ \\
Av. Initial Body Wt. (g) & 121.3 & 124.7 & 141.9 \\
Av. Final Body Wt. (g) & 130.5 & 132.8 & 160.5 \\
Av . Weight Gain (g) & $9.2^{\mathrm{a}}$ & $8.1^{\mathrm{a}}$ & $18.6^{\mathrm{a}}$ \\
Av. Initial Shell Length (cm) & 11.7 & 12.0 & 12.1 \\
Av. Final Shell Length (cm) & 12.0 & 12.2 & 12.3 \\
Av. Shell Length Increase (cm) & $0.3^{\mathrm{a}}$ & $0.2^{\mathrm{a}}$ & $0.2^{\mathrm{a}}$ \\
Av. Initial Shell Circumference (cm) & 16.2 & 16.8 & 16.7 \\
Av. Final Shell Circumference (cm) & 16.5 & 17.4 & 17.1 \\
Av. Shell Circumference Increase (cm) & $0.3^{\mathrm{a}}$ & $0.6^{\mathrm{a}}$ & $0.4^{\mathrm{a}}$ \\
Mortality / Survival Percentage & $0(100 \%)$ & $0(100 \%)$ & $1(87.5 \%)$ \\
\hline
\end{tabular}

${ }^{*}$ All values with the same superscripts within rows are not significantly different $(P>0.005)$.

( $p>0.05 \%$ ) from that of pawpaw leaves whereas dry matter intakes in pawpaw fruit and cabbage leaves are not significantly different from each other. The highest dry matter intake of $0.27 \mathrm{~g} /$ snail /day was obtained in cabbage leaves while pawpaw leaves had the least dry matter intake of $0.19 \mathrm{~g} / \mathrm{snail} /$ day. On the other hand, the highest feed conversion ratio (FCR) of (1.3) was obtained in pawpaw fruit followed by pawpaw leaves (1.1), while cabbage leaves recorded the least (0.8). This probably could be as a result of the tiny and delicate teeth-like organ (Radula) in snails which make it preferred feeding on succulent, low-fibre feeds to others (Omole, 1998). Cabbage and pawpaw fruit have low fibre content of 2.0 and 1.8 respectively.

The highest average weight gain of $18.6 \mathrm{~g}$ was obtained in snails fed with cabbage leaves while pawpaw leaves had the least value, though there was no significant difference among the mean values. Pawpaw fruit and leaves supported increase in shell length and circumference respectively. No significance differences among the values obtained for size increase.

Only one mortality was recorded in the treatment fed with cabbage leaves, indicating a survival percentage of $87.5 \%$.

\section{Conclusion}

The rate of consumption of pawpaw fruit, leaves and cabbage leaves by snails indicated that they are highly cherished by snails. Natural feedstuff is required for feeding snails in captivity because they depends partially on leaves and fruits in the wild. Pawpaw fruit and leaves are good natural feedstuffs for feeding snails, but the fruit is seasonal and it also serves as food for human being. Cabbage on the other hand is available through out the year, easily assessable and inexpensive. Cabbage peels could be obtained from foreign vegetable stores at little or no cost.

\section{Recommendations}

The results indicated that snails fed with cabbage leaves performed better than the other two natural feedstuffs in terms of weight gain and that cabbage peels are easily accessible and cheaper to obtain than pawpaw fruit and leaves which equally is an important food item for man. It can, therefore, be recommended that cabbage peels should be used for feeding snails in order to avoid unnecessary competition with man for pawpaw and its associated products.

\section{REFERENCES}

Ademolu KO, Idowu AB, Mafiana CF, Osinowo OA (2004). Performance, proximate and mineral analyses of African giant land snail (Archachatina marginata) fed different nitrogen sources. Afr. J. Biotechnol. 3(8): 412-417.

Akinnusi $O$ (1998). Introduction to snails and snail farming. Omega Science Publishers, Lagos, p. 70.

Amusan JA, Omidiji MO (1999). Edible land snail: A technical guide to snail farming in the tropics. Verity Printer Limited, Ibadan. pp. 5-50.

Bello MO, Falade OS, Adewusi SRA, Olawore NO (2008). Studies on the chemical composition and nutrients of some lesser known Nigerian fruits. Afr. J. Biotechnol. 7(21): 3772-3879 $5^{\text {th }}$ Nov., 2008.

Hamzat RA, Jaiyeola CO, Longe OG (2002). Nutritional qualities of snails (Archachatina marginata) fed solely with fresh kola testa. Nutri. Food Sci. 32(4-5): 134-136.

Eruvbetine D, Oguntona EB, Adeoye UA (1997). Preliminary studies comparing different diets for intensive rearing of snail. Proceedings of the biennial Conf. of the Ecological Society of Nigeria (ECOSON). University of Agriculture, Abeokuta, Ogun State. $23^{\text {rd }}-27^{\text {th }}$ Nov. 1999.

Food and Agriculture Organisation FAO (1986). Farming snail by FAO Better Farming Series, 3/33 Rome, Italy .

Odunaiya $O$ (1997). Snail rearing techniques and marketing strategies. Prepared for Boom and Praise Projects, Iworo-ljebu, Nigeria. p. 27.

Omole AJ (1998). Utilisation of different energy supplements on the 
performance characteristics of growing snail (Archachatina marginata). M.Sc. Thesis. Department of Animal Science, Faculty of Agriculture \& Forestry, University of Ibadan, Ibadan. p. 75.

Osawuyi YA (1989). Practises guide to snail rearing. Gratitude Enterprises, Lagos. p. 27.
Steel RGD, Torrie JH (1980). Principle and procedures of statistics. $2^{\text {nd }}$ edition. McGrawn-hill Book Company Inc., New York. 